\title{
Building Relationships between Museums and Schools: Reggio Emilia as a Bridge to Educate Children about Heritage
}

\author{
Maria Feliu-Torruella *(D), Mercè Fernández-Santín (D) and Javiera Atenas \\ Department of Applied Pedagogies, Faculty of Education, University of Barcelona, 08035 Barcelona, Spain; \\ merce.fernandez.santin@gmail.com (M.F.-S.); javiera.atenas@ub.edu (J.A.) \\ * Correspondence: mfeliu@ub.edu
}

Citation: Feliu-Torruella, M.; Fernández-Santín, M.; Atenas, J. Building Relationships between Museums and Schools: Reggio Emilia as a Bridge to Educate Children about Heritage. Sustainability 2021, 13, 3713. https://doi.org/10.3390/su13073713

Academic Editors: Cosme

Jesús Gómez-Carrasco,

José Monteagudo-Fernández,

Pedro Miralles-Martínez and

Olaia Fontal-Merillas

Received: 8 March 2021

Accepted: 20 March 2021

Published: 26 March 2021

Publisher's Note: MDPI stays neutral with regard to jurisdictional claims in published maps and institutional affiliations.

Copyright: (c) 2021 by the authors. Licensee MDPI, Basel, Switzerland. This article is an open access article distributed under the terms and conditions of the Creative Commons Attribution (CC BY) license (https:/ / creativecommons.org/licenses/by/ $4.0 /)$.
Abstract: Schools and museums represent essential spaces for the development of learning and understanding of the world surrounding us through the arts and heritage. One of the things learned in the COVID crisis is that it is key to build bridges between schools and museums to support their educational activities, regardless of the possibility to access these spaces in person. School teachers and museum educators have the opportunity to develop a critical and creative citizenry by collaborating in the design of learning activities that can bring the museums to schools and schools to the museum by adopting the Reggio Emilia approach. The results of the study arise from a triangulation of data, as we contrasted the literature about the Reggio Emilia approach with the practices of museums that use such a philosophy and with the analysis of a series of interviews with experts in early childhood education and Reggio Emilia in order to identify a series of good practices, which we used to delineate recommendations to foster the adoption of this model and establish relationships between schools and museums, enhancing the opportunities to develop critical and creative thinking throughout activities and to understand the heritage and the arts, thus fostering citizenship from an early childhood.

Keywords: Reggio Emilia; cultural heritage; education; early childhood; open education; open educational resources

\section{Introduction}

Schools and museums are key spaces for the individual and collective learning of the arts and heritage, which can be seen as a vehicle for understanding society. Thus, education through heritage allows us to connect with the idea that we are part of a community. By interacting with the world, we note that all are part of a collective history, as well as individuals with a personal story. Understanding this abstract idea is fundamental for learners and thus of special significance in early childhood education, which is a stage where we must help children learn to develop empathy and a sense of community. Hence, it is essential that schools introduce heritage education in early childhood, bringing children to visit museums and heritage sites to start establishing emotional ties with the spaces that surround us with the aim of building a responsible, critical and committed citizenship. Therefore, it is key to establish collaborations between museums and schools to develop joint programmes grounded in the value of the arts and heritage for education.

We consider that it is essential to develop pedagogical methodologies to foster relationships between museums and schools and enable approaches that share educational values in curricula, teaching with arts and heritage. As museums (or heritage sites) and schools share lots of commonalities and spaces that allow through play, exploration and dialogue the chance to have experiential and inclusive learning experiences via innovative and experimental pedagogies, and as childhood education has been redefined towards a more dynamic and inclusive educational model in which students have experiences that stimulate cognitive development, in this study, we propose guidelines for the adoption of the pedagogical model of Reggio Emilia (RE) to create partnerships between schools and museums. 
The RE model holds a long, pedagogical tradition in promoting the learning of the arts and heritage to foster critical thinking through creativity, dialogue, collaboration and observation of the environment from early childhood in schools and museums [1-3]. This pedagogical approach conceives the school as a living organism in which learning is co-constructed between educators and students through experimentation and dialogue [4], as well as throughout the interactions between children, the environment and society, which indeed includes museums [5]. Thus, the RE model can act as a bridge between the educational aims of schools and museums, promoting educational innovation as a model for the development of social and cognitive skills [6,7].

RE schools have more in common with museums than with many schools, since these are aware that the space in which a child learns is not only a passive container for information [8], but it is also a form of information itself. Thus, they share philosophies and key educational practices, as both RE schools and museums are aware that not only do people influence learning, but they also understand the impact of the physical world [9-11].

In early childhood, the development of cognitive processes is related to social interaction, communication, play and exploration [12], so learning in the RE model is not limited to the classroom, as it promotes the inclusion of broader experiences, favouring social interactions and conversations between adults and children while fostering peer learning throughout experimentation and research $[1,13,14]$. As such, the educational role of museums can be crucial in encouraging dialogue and participation to promote the development of critical and social skills.

Since its creation, RE has had heritage education at its core. It is understood as an educational vehicle and a shared space of common responsibility, as RE is grounded in education for peace. Days after the end of the Second World War in 1945, with the money obtained from the sale of horses, a tank and a truck abandoned by the Germans after their defeat in Italy, a group of families decided to build self-managed schools [1]. The barbarities experienced during the war gave them the conviction that by working from the schools, they could avoid resorting to armed conflicts to solve problems, instilling the values of collaboration and critical thinking to create free and democratic societies. RE schools thus arise from the will of families to recover their heritage, with the conviction that education is what sets people free.

In the RE model, it is important to be able to accompany students in the exploration of knowledge, creating environments for learning that allow observing, experimenting, investigating and asking questions about the world. Therefore, it is essential to carry out projects that help to structure teaching and learning processes [15] so learners can benefit from diverse educational experiences, which include visits to museums and also activities that museums can provide to schools [1,4,6,16-22].

During the crisis brought by the COVID-19 pandemic, we have seen the immense efforts that museums and other cultural and heritage institutions have made to provide open, unlimited and borderless access to culture and cultural and artistic heritage, bringing their collections closer to the public. Enabling activities around them, such as virtual tours, concerts, talks, podcasts, conferences, games and many others, they provide to a wide and international audience invaluable access to learning, which is extremely beneficial for students and educators around the world. Thus, this interaction between museums, teachers and students has generated new learning spaces that go beyond the classroom, bringing museums closer to schools and vice versa, and it is key that these are preserved after the crisis has passed.

Partnerships and collaborative activities between museums and schools must aim at promoting the development of creative and critical thinking, using artistic and heritage collections as a vehicle for the co-creation of knowledge, which is key in the RE model. Therefore, in this study, we ask ourselves the following: Which role should schools and museums adopt to foster the development of skills for civic participation, understanding of cultural diversity and peace education through dialogue from early childhood? How 
can the RE model build bridges to promote education by catalysing the educational power of museums?

Our objective is to present to the school and museum communities a series of guidelines to establish collaboration channels in physical and digital spaces, based on the pedagogical principles of the RE model. We aim at highlighting good practices to facilitate museum-school relations in an open, participatory and democratic way in order to promote the development of activities that stimulate cognitive development and critical thinking from early childhood.

\section{Justification}

RE's pedagogical philosophy is influenced by educators and psychologists such as Dewey, Piaget, Vygotsky, Montessori, Bronfenbrenner and Bruner [23]. According to Cutcher [24], RE is grounded in Vygotsky's sociocultural theories and in constructivist learning, as well as Dewey's notion of art as experience. In these theoretical contexts, educators play a key role in the learning process of children. Vygotski's theories argue that the educator, through experimentation, creates a beneficial environment for children's cognitive activity, stimulating research through the discovery and deepening of a problem, posing questions and generating hypotheses [25-29].

The importance of studying the arts and cultural heritage from the early years of education, especially in the context of experiential education, lies in the need to facilitate children's seeing the world with different eyes, exploring materials through their senses, experimenting with new techniques and learning about the world through a multisensory approach. Thus, having encounters with the arts, whether in the school atelier, in museums or in the streets and in public spaces, observing artworks, objects and places is important to help children improve their perceptual skills and nurture the pleasure of enjoying and creating art by bringing art and cultural heritage to children [30-36].

Creativity is often an autonomous activity that requires independence, so it is important for RE schools to have creative, unusual and open structures and playing spaces that foster creativity by enabling channels for social learning [37-41]. However, for Torrance [42], Runco and Jaeger [43] and Runco et al. [44], students were more creative when they were alone or when they were out of school. Thus, the role of museums in the RE model is crucial, as they must invite students to explore them or bring their experiential activities into schools [21].

There are different pedagogical models that can be useful and successful in connecting the activities of museums and schools which have been and currently are used in educational centres, such as Montessori, Creative Curriculum, Inquiry and Constructivism, Experiential Learning and Visual Thinking Strategies. However, we consider that the RE model, as a pedagogical approach, is quite comprehensive and inclusive. Therefore, it is relevant and useful for establishing bridges between schools and museums, connecting learners, educators, spaces and activities while putting children, from a very young age, at the centre of their learning, giving them agency and ownership in the co-construction of knowledge.

A key element for experimentation and innovation is the learning space. Therefore, RE schools have a very special classroom called the Atelier, which is a carefully designed and welcoming classroom where creativity is developed through activities with a wide range of materials and experiences. This type of space also exists in many museums, since it emulates the artist's workshop or is an experimental room, which helps children to comprehend arts and heritage from within, facilitating the understanding of the world through projects prepared according to the children's needs [45-49]. For Falk and Dierking [50] and Kirk [8], the learning model proposed by museums was experiential and depended on personal, sociocultural and spatial contexts. Therefore, these synergies between RE school methodologies and museums favour creative teaching methods that allow children to explore, co-create and express their ideas [51,52]. 
In the RE model, the environment is considered an educator [1,53,54], and it is understood that children create and give meaning to their world in the context of the physical environment through their constant interactions and relationships between the world and the people by sharing ideas. Therefore, it is important to facilitate many possibilities to explore by using a wide range of materials both in the school and in museums, as rich and dynamic environments are valued as places full of information and objects that enable social interactions, using museum collections as a vehicle to understand students' learning processes through the different ways in which children express themselves, including visual and body language, music, dance and play [49,55-58].

Both in the Atelier of the schools and in museums, educational projects and activities must arise from the interests and experiences of children, allowing them to explore and answer the questions they have about the world, since through these projects, students can learn by discussing their discoveries with others [59-62]. In the RE model, students learn through the negotiation of ideas, co-constructing knowledge through social interaction, so we consider that by establishing a series of guidelines and good practices for a pedagogic and educational exchange between museums and schools, we can contribute to broadening the opportunities for the development of a creative childhood which will grow capable of critically solving problems through dialogue $[1,45,63,64]$.

\section{Methodology}

For this study, we have done a triangulation of data and information analysis, as we have reviewed the literature of the area to explore how museums use the RE model and contrast both elements with the analysis of a series of interviews with experts in the area of the RE model and early childhood education, obtaining relevant criteria that allow us to draw good practices and thus propose a series of guidelines for museums and schools to foster the development of skills in early childhood through creativity.

We first reviewed the literature following an integrative model, as we analysed different streams of research using an interdisciplinary approach towards mapping practices which could be deemed relevant to establishing partnerships between museums and schools. Subsequently, we reviewed the educational programmes of museums that have adopted the pedagogical approach of RE in their educational units to be able to extrapolate these practices both in schools and in other museums. Finally, to understand which practices could be adopted by schools and museums from the professional perspective of experts in childhood education and the RE model, we conducted a series of interviews with a group of international experts, and we asked them what they would like to see in a partnership between schools and museums.

\subsection{Literature Review}

To understand how to bring the pedagogical approaches of both museums and schools closer and to comprehend which learning activities could be considered transversal, transferable and adaptable for developing creative and critical skills in early childhood, we conducted a comprehensive integrative literature review $[65,66]$, notwithstanding the fact that we used some techniques of literature surveying from the systematic review model $[67,68]$ in order to select the most relevant experimental and theoretical literature alongside case studies to understand the key elements of the relationships and pedagogies of museums and schools, following the recommendations of Rocco and Plakhotnik [69] and Torraco [70].

To analyse a wide spectrum of potentially relevant literature, we conducted an initial search using Google Scholar, which is a comprehensive interdisciplinary aggregator of academic databases, following the guidelines of Martín-Martín, Orduna-Malea and Delgado López-Cózar [71]. The search terms used and the resulting number of records found prior to the documentary selection process can be understood as follows:

- Young children visit museum, $\mathrm{n}=1,080,000$;

- Young children museum spaces, $\mathrm{n}=396,000$;

- $\quad$ Artistic education for children, $\mathrm{n}=785,000$; 
- $\quad$ School museum collaboration, $\mathrm{n}=880,000$;

- School museum partnerships, $\mathrm{n}=318,000$;

- Educators' museums training, $\mathrm{n}=128,000$;

- Early childhood education museum, $\mathrm{n}=649,000$;

- Reggio Emilia approach museum, $\mathrm{n}=9300$;

- Heritage education, $\mathrm{n}=3,740,000$;

- Heritage education primary school, $\mathrm{n}=2,390,000$;

- Knowledge construction Reggio Emilia, $\mathrm{n}=23,200$;

- Critical thinking reggio emilia, $\mathrm{n}=19,400$;

- Open education museums, $\mathrm{n}=5160$.

From the total number of results found, an initial group of 537 articles were downloaded and preselected as the potentially useful literature. In addition, a mapping was made for the database of university journals, which gave us another 85 potential articles to include in this preselection. In this way, we were able to narrow down and filter the information obtained. We used the PRISMA model for the systematic review of the literature [72] to select those studies relevant to this article, excluding those that did not meet the thematic and quality requirements and those that were outside the limits of this study (see Figure 1).

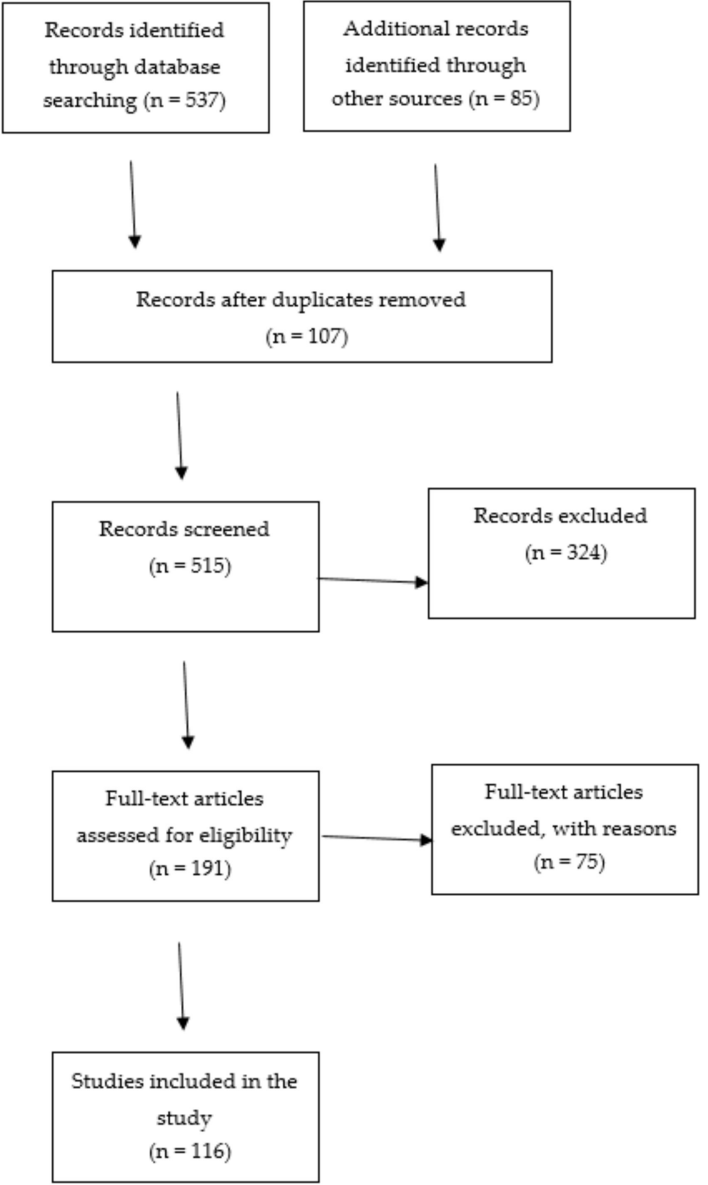

Figure 1. The literature review process.

For each topic, we then selected a group of relevant studies which we reviewed from an interdisciplinary perspective, gathering their different ideas and key elements to make a map of interesting practices to promote collaboration between museums, schools, museologists and teachers towards developing critical and creative skills in childhood, promoting the co-creation of knowledge through open educational practices. 


\subsection{Analysis of the Practices of Museums}

For this study, we needed to understand how museums teach school-age children, so we reviewed 85 museum portals of different types, such as national and local museums, and identified 29 that had early childhood education programmes. Of these 29, 14 declared use of the RE pedagogical model, so we studied the different dimensions of these museums to identify the practices and pedagogies they used and select activities that could be used by educators in schools and other museums (see Figure 2). For the analysis, we established those fundamental aspects of an educational project that we wanted to identify: what role is given to the RE philosophy, how should the adult behave in educational action, and what is the role of the students?

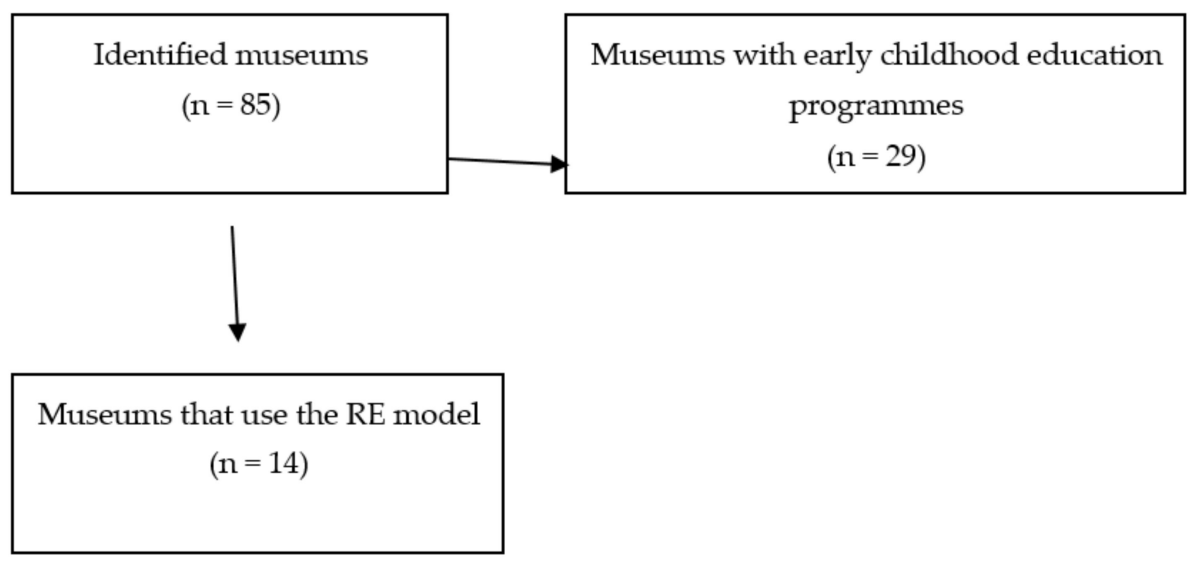

Figure 2. Museum analysis.

From the 85 identified museums, of the 29 museums that had early childhood education programmes, we identified 14 that adopted the RE model and 15 that had programmes grounded in other philosophies and approaches, such as Montessori, Creative Curriculum, Inquiry and Constructivism, Experiential Learning and Visual Thinking Strategies. The remaining 56 museums did not have early childhood education programmes. Instead, their educational programmes and activities were designed for children over six years old (primary schools) or for teenagers (middle and secondary schools).

\subsection{Expert Interviews}

Furthermore, for this research, we recruited 14 internationally recognised specialists in the RE model, early childhood education and critical thinking who were selected through the recommendations made by a group of academic experts. Taking into account ethical issues, all interviewees gave their explicit consent to participate. Thus, their anonymity was guaranteed, following the European General Data Protection Regulation 2016/679 (GDPR). The semi-structured interviews were designed around the central axes of the RE model $[73,74]$ to be able to portray the role of RE pedagogies from various dimensions and perspectives and identify recommendations, ideas and models for developing creative and critical skills through the collaboration between museums and schools. All the interviews were recorded using a voice notes application, obtaining $17 \mathrm{~h}$ of recordings and transcriptions from which the data analysis for this study was carried out.

\section{Literature Review}

To understand the approaches and techniques that schools and museums should adopt to promote the development of creative and critical skills from early childhood, and how the RE model can build bridges to catalyse the educational power of museums, we studied the literature to string together the key elements and connect the educational approaches of schools and museums. 
Most of the educational programmes of museums thrive through school visits, as they aim at having an effect on the students who visit them. Therefore, it is necessary that schools and museums co-design plans by establishing shared objectives and developing collaborative programmes. According to Downey, Delamatre and Jones [75] and Bobick and Hornby [76], school-museum programmes should establish open communication channels to develop educational curricula and foster critical thinking and creative skills by employing two main approaches to teaching: inquiry and practical artistic creation [77].

The learning potential of museum-school partnerships is related to the levels of satisfaction that can create shared learning experiences and opportunities, generating emotions in students through experiences that stimulate interest in learning through artistic experimentation $[28,78,79]$, and for the development of these programmes, the RE model offers opportunities to link school learning with the educational programmes of museums.

Collaborations between museums and schools should be born out of common interests, as well as from national and regional educational needs to enable students a unique environment for this experience while building on what they are learning in the classroom $[79,80]$. Therefore, it is important that museums understand the national or regional curricula and strategies to develop action plans that facilitate interactions with schools through visits and by providing teaching and learning resources to schools. According to Adams, Luke and Witmer [78], Witmer [81] and Gupta, Adams, Kisiel and Dewitt [40], designing programmes that feature multi-visit activities can have a profound and longlasting impact on students, enhancing their ability to respond to and discuss heritage while supporting educational standards and classroom work.

When co-designing educational journeys, museums must understand the socioeconomic context and needs of schools, and schools must understand the limitations that museums have to establish fair, collaborative programmes. For example, they can jointly develop activities that allow schools to extrapolate the museum experience or schedule museum visits to the classroom, both physically and virtually, and design educational materials which can be loaned to schools while training the schoolteachers to feel comfortable using such educational resources $[15,28,51,79,80,82]$.

In the RE model, we can observe a series of elements or foci of action that can facilitate the design of educational programmes and pedagogic activities, which we describe as the eight axes of RE [73,74], which allow us to outline guidelines for museums and schools to adopt the principles and methods of RE towards fostering the development of creative and critical skills through experimentation, exploration and dialogue from early childhood, creating bridges for collaboration between both museums and schools.

The first element to consider is the environment as a third teacher, as in the RE model, the spaces that invite one to explore, investigate and experiment are considered educational agents themselves, in particular the classroom atelier which, through its aesthetics and accessible components, invites the students to investigate and experiment, asking questions about the world around them. Therefore, a wide variety of materials should be provided to students to experiment, create, interact and express themselves $[4,19,29,53,74,77,83]$, while the atelierist, the person in charge of the atelier who works with other teachers and students, accompanies the children in their discoveries, offering opportunities to experiment and innovate at a pedagogic level, bridging the curriculum and artistic creation to give students a voice $[48,49,54,73,84,85]$.

The children's questions and their way of answering them are noted under what the RE model describes as the hundred languages of the child. As Vecchi [49] explains, in the $\mathrm{RE}$ approach, the concept of language extends beyond verbal language and is understood as the different ways humans use to express ourselves. Thus, this model encourages exploration and curiosity, motivating children to investigate their environment to the fullest. According to Loh [60] and Schroeder-Yu [54], in the RE model, the students are considered competent, resourceful, curious, imaginative and inventive and possess a desire to interact and communicate with others. Thus, the arts and heritage become a vehicle to understand students' thinking processes [56]. 
Numerous voices promote the possibility of developing critical thinking through the arts and heritage in nonformal educational contexts, such as in museums and heritage centres, so long-term pedagogic projects are key to co-designing transversal and collaborative activities between museums and schools through the infinite possibilities offered by museum collections to develop communication skills and critical thinking by bringing students closer to works of art and heritage spaces, encouraging observation and using various materials as a means of expression [60,61,86-89].

In museums and schools, it is important that teachers who work on educational projects with infants are teacher-researchers, as they must not only guide them, but also listen, observe and document their work. In the RE approach, students co-construct knowledge through group work and the discussion of ideas, giving special importance to debates and cooperative problem solving between students $[63,64,90]$. Educators should develop research that allows them to design pedagogic activities and co-construct knowledge through discussions with others, investigating methods that encourage children to explore their environment and fostering curiosity in all areas where children can grow, helping students develop critical thinking, creativity and collaboration through art [1,2,54,84,91,92].

The educational projects that museums and schools co-develop, according to the RE model, must be focused on the image of the child, who is considered per se as creative, curious, full of potential and ambition. According to Malaguzzi [1], from an early age, people are capable of constructing their own learning, as they learn through curiosity, research, exploration and experimentation, as well as through communication and socialization $[3,93]$. Therefore, children learn together, collaborating with each other while also creating an image of themselves by developing cognitive, physical, social and linguistic skills, which allows them to acquire independence and confidence by making their own decisions and responding to their own problems [6,94-99].

One of the recommended strategies for the development of innovative pedagogies in museums and schools is to foster negotiated learning, which can facilitate the development of transversal skills such as critical thinking [73,74] by promoting dialogue between community members and fostering the co-creation of knowledge through collaboration in an activity $[61,86,87,95,100]$. In the RE approach, the arts and heritage are used as a channel for expression, since they favour the development of creativity. Therefore, teachers must plan activities to promote problem solving and creative skills and to develop the languages of children through materials that allow children to create while their teachers guide them to learn in a collaborative, creative, flexible and critical way [58,101-109].

One of the ways in which it is recommended to design educational activities that can be adopted interchangeably in museums and schools is by favouring what in the RE model is described as the documentation process in which, starting from photographs, videos, notes, and recordings, it is possible to present and represent students' experiences, thoughts and ideas and show their learning process to assess the importance and relevance of children's work and make it visible. Therefore, to promote interaction and communication between museums and schools, exchanging documentation and the work carried out in the respective ateliers can offer opportunities to innovate and adapt ideas to experiments $[6,49,59,84]$, since the use of documentation can progressively help to improve educational practices.

Finally, the RE model promotes the establishment of social relationships. The exchange between the communities of schools and museums is key, as the RE model encourages the development of knowledge about the world in a critical way through the subjects and objects within it, involving teachers in student learning and establishing relationships between the schools and society, as students must interact and communicate with each other to learn $[46,60,61,103-105]$.

In addition to these eight key elements of the RE approach, the literature currently points to the need to open up access to educational activities that take place in museums and schools by sharing pedagogical practices through the use of technology, thus bringing together communities that can be separated by geographical distances through a model 
proposed by UNESCO $[110,111]$ known as open education, which is understood as a democratic way to reduce educational gaps by opening up open educational resources (OERs) and activities so educational communities can make the most of available educational materials.

The value of open education is that it can help to establish relations between museums and schools, as open education goes beyond the digitisation of collections, including a range of democratic educational practices that aim to open up pedagogic activities, facilitate the exchange of teaching practices and promote the creation and sharing of open educational resources (OERs) [112-114]. Thus, to bring the educational practices of museums and schools closer and the activities of school and museum educators together [79,109], they can share and co-design curricula, in person or online, to establish links, share ideas and propose joint activities promoting the use of museum content as teaching tools that foster creativity and critical thinking [115-118].

Taking students to a museum or bringing a museum to the classroom, be it physically or digitally, changes and instantly enriches the dynamics of the usual learning environment [5], providing teachers with innovative tools and opportunities to interact with students in creative ways [119-122]. To establish links between museums and schools, open education is a democratic vehicle that promotes mutual learning and makes the most of museum collections by allowing educators to access materials as OERs and the educational activities developed around these [123-126].

\section{Results}

To understand the approaches and techniques that schools and museums should adopt to promote the development of creative and critical skills from early childhood and how the RE model can build bridges to catalyse the educational power of museums, we studied the literature to string together the key elements and connect the educational approaches of schools and museums.

\subsection{Educational Practices of RE in Museums}

Both in schools and museums, educational spaces should be designed with a series of pedagogic activities in mind that promote individual and collective learning [40,51]. Therefore, it is necessary to establish channels for collaboration and dialogue between them to co-design joint or complementary programmes that reflect the education and learning objectives towards integrating their educational communities in the development and design of the curriculum $[76,79,80,82,127,128]$.

For the RE approach, one of the key aspects is caring for the environment (e.g., the classroom atelier, the furniture and the materials), considering aspects such as aesthetics and accessibility $[47,53,54]$. Therefore, spaces should promote the development of individual or collective experimental activities that allow infants to explore and negotiate while educators document their learning processes $[1,47,48,129]$. We have to consider that the educational actions of museums should be conceived as a whole, in which their educators, the museum, its collections and the space where the action takes place intervene. It is at this point that the educational actions of museums and the RE philosophy establish bridges, since for the RE approach, the environment is indeed a third teacher.

The museums that we studied to understand how they adopted the RE model to develop activities can be seen in Table 1 .

To provide a comparative overview, we listed below other museums reviewed for this study that had early childhood educational programmes but had not adopted an RE approach. These can be relevant to understanding how museums develop their learning strategies and how these different approaches can be included, alongside the RE model, into strategies to bridge museum and school activities and enhance the learning experience of students, as these approaches are complementary (see Table 2). 
Table 1. Use of the Reggio Emilia (RE) approach in museums.

\begin{tabular}{|c|c|c|}
\hline Museum & Philosophy & Link (Accessed on 24 March 2021) \\
\hline $\begin{array}{l}\text { The Eric Carle Museum } \\
\text { of Picture Book Art }\end{array}$ & $\begin{array}{l}\text { The RE pedagogy is used in this museum with the aim of enveloping the user and entering } \\
\text { into a natural connection with the artistic language. }\end{array}$ & $\begin{array}{l}\text { https://www.carlemuseum.org/content/reggio-emilia- } \\
\text { inspired-programs }\end{array}$ \\
\hline Portland Children's Museum & $\begin{array}{l}\text { Starting from the basic principles of RE pedagogy, the educational project of this museum } \\
\text { aims to give a fundamental role to boys and girls in the construction of their learning. }\end{array}$ & https://www.portlandcm.org/about-us/our-philosophy \\
\hline $\begin{array}{l}\text { Imagine Nation, A Museum Early } \\
\text { Learning Center }\end{array}$ & $\begin{array}{c}\text { Cooperation is the basis of the educational project of this facility, understood as a } \\
\text { fundamental axis between life, adults and children. }\end{array}$ & https://www.imaginenation.org/reggio-emilia-philosophy1 \\
\hline $\begin{array}{l}\text { The Strong National Museum } \\
\text { of Play }\end{array}$ & $\begin{array}{l}\text { Again, cooperative work between students and teachers appears as the basis of the } \\
\text { museum's educational project in order to create projects and build the curriculum. }\end{array}$ & $\begin{array}{c}\text { https://www.museumofplay.org/education/woodbury- } \\
\text { school/reggio-emilia }\end{array}$ \\
\hline $\begin{array}{l}\text { The Children's Museum of } \\
\text { Southern Oregon }\end{array}$ & $\begin{array}{l}\text { In this museum, it is assumed that children are explorers by nature and that the role of the } \\
\text { adult is to facilitate this exploration. }\end{array}$ & $\begin{array}{c}\text { https: / /www.kid-time.org/single-post/2017/06/16/Reggio- } \\
\text { Montessori-and-Waldorf-Oh-My }\end{array}$ \\
\hline Miami Children's Museum & $\begin{array}{l}\text { The principles of respect, responsibility and community govern the central idea of the } \\
\text { educational project of this museum, also inspired by the pedagogy of RE. }\end{array}$ & https://www.miamichildrensmuseum.org/preschool/ \\
\hline $\begin{array}{l}\text { Museu de les Ciències } \\
\text { de Barcelona }\end{array}$ & $\begin{array}{l}\text { The principles of respect, responsibility and community govern the central idea of the } \\
\text { educational project of this museum, also inspired by the pedagogy of RE. }\end{array}$ & $\begin{array}{l}\text { https: } \\
\text { //edunat.museuciencies.cat/projectes/el-niu-de-ciencia/ }\end{array}$ \\
\hline Museo Thyssen-Bornemisza & $\begin{array}{l}\text { With its En Abierto project, it offers proposals for educational activities and actions aimed } \\
\text { at schoolgirls and students to carry out in the museum or in the classroom. }\end{array}$ & $\begin{array}{c}\text { https: } \\
\text { //www.educathyssen.org/profesores-estudiantes/abierto }\end{array}$ \\
\hline $\begin{array}{l}\text { Museo Universitario de Arte } \\
\text { Contemporáneo (México) }\end{array}$ & $\begin{array}{l}\text { From the museum, proposals are generated for the development of creative and critical } \\
\text { skills through the approach of infants for the use of the languages of contemporary art. }\end{array}$ & https://muac.unam.mx/infantiles \\
\hline Whitney Museum of American Art & $\begin{array}{l}\text { This museum offers students proposals to generate critical discussions about art, } \\
\text { think creatively and create jointly with contemporary artists, educators and peers. }\end{array}$ & https://whitney.org/Education/Teens \\
\hline $\begin{array}{l}\text { The Children's Museum } \\
\text { (Indianapolis) }\end{array}$ & $\begin{array}{l}\text { The goal of this museum is to create learning experiences through the arts, sciences and } \\
\text { humanities to transform the lives of children and families. }\end{array}$ & https://www.childrensmuseum.org/about/preschool \\
\hline Children's Museum of Richmond & $\begin{array}{l}\text { Based on the RE philosophy, this museum offers activities that encourage children to } \\
\text { discover their own answers through play for children between the ages of } 18 \text { months and } \\
5 \text { years. }\end{array}$ & $\begin{array}{l}\text { https://www.childrensmuseumofrichmond.org/ } \\
\text { community/sprout-school/ }\end{array}$ \\
\hline Bay Area Discovery Museum & $\begin{array}{c}\text { Museum inspired by RE's learning philosophy, basing its experiences on respect for } \\
\text { children and their abilities. }\end{array}$ & $\begin{array}{c}\text { https://bayareadiscoverymuseum.org/preschool/about-us / } \\
\text { our-approach }\end{array}$ \\
\hline Musei Civici Reggio Emilia & These museums aim to stimulate interpretation skills and personal reworking. & $\begin{array}{c}\text { https: } \\
\text { //www.musei.re.it/il-museo-per-la-scuola/per-la-scuola/ }\end{array}$ \\
\hline
\end{tabular}


Table 2. Use of the other learning approaches in museums.

\begin{tabular}{|c|c|c|}
\hline Museum & $\begin{array}{l}\text { Philosophy } \\
\text { (Montessori, Creative Curriculum, Inquiry and Constructivism, Experiential } \\
\text { Learning and Visual Thinking Strategies) }\end{array}$ & Link (Accessed on 24 March 2021) \\
\hline Museum of Modern Art (Moma) & Visual Thinking Strategies & $\begin{array}{l}\text { http://www.pz.harvard.edu/projects / momas-visual- } \\
\text { thinking-curriculum-project }\end{array}$ \\
\hline Fundació Joan Miró & Experiential Learning and Visual Thinking Strategies & $\begin{array}{l}\text { https://www.fmirobcn.org/es/actividades/centres- } \\
\text { educatius/educacion-infantil/27/el-mundo-de-miro }\end{array}$ \\
\hline Museo Nacional Centro de Arte Reina Sofía & Experiential Learning & $\begin{array}{l}\text { https:/ / www.museoreinasofia.es/actividades/tablero- } \\
\text { invisible-2018 }\end{array}$ \\
\hline British Museum & Visual Thinking Strategies, Inquiry and Constructivism & https://www.britishmuseum.org/learn/schools/ages-3-6 \\
\hline Museu Picasso de Barcelona & Visual Thinking Strategies & $\begin{array}{c}\text { http://www.bcn.cat/museupicasso/es/educacion/el- } \\
\text { museu-en-la-escuela.html }\end{array}$ \\
\hline Museu Nacional d'Art de Catalunya & Visual Thinking Strategies, & https://www.museunacional.cat/es/escoles-tandem \\
\hline Museo Larco & Inquiry and Constructivism, Visual Thinking Strategies, Experiential Learning & $\begin{array}{c}\text { https://www.museolarco.org/educacion/visitas- } \\
\text { escolares/?origin=71 }\end{array}$ \\
\hline Van Gogh Museum & Creative Curriculum, Inquiry and Constructivism & $\begin{array}{l}\text { https://www.vangoghmuseum.nl/nl/bezoek/ } \\
\text { schoolgroepen\#basisscholen }\end{array}$ \\
\hline Kansas Children's Discovery Center & Montessori & https://kansasdiscovery.org/ \\
\hline National Museum of Modern and Contemporary Art, Korea & Creative Curriculum, Experiential Learning & http://www.mmca.go.kr/learn/introduce.do \\
\hline Smithsonian Museum & Montessori, Inquiry and Constructivism & https://www.si.edu/SEEC \\
\hline The J. Paul Getty Museum & Visual Thinking Strategies & $\begin{array}{c}\text { https://www.getty.edu/education/teachers/professional_ } \\
\text { dev/creative_core/ }\end{array}$ \\
\hline National Gallery of Art & Visual Thinking Strategies & $\begin{array}{l}\text { https://www.nga.gov/education/teachers/art-around- } \\
\text { the-corner.html }\end{array}$ \\
\hline
\end{tabular}


There is a certain agreement in the adoption of philosophical models that allows generating spaces for the development of creative and critical thinking through artistic language, the sciences and humanities and the connection with the arts [74]. In order to develop critical thinking in museums, it is necessary to leave room for the elaboration of approaches and the joint construction of learning, and this can be done when the museum's proposal is open enough in its didactic approach to leave room for action.

It is also deduced from the analysis that in most of the museum studies, as there was an agreement about the protagonist role given to students in the acquisition of learning, there was a point of convergence in which the child was at the centre, and thus the learning approaches of museums that adopted the RE approach conceived the child as an active actor in the construction of their learning, which implies exercising a responsibility towards their community in order to generate cooperative projects between museums, teachers, students and families.

\subsection{Analysis of the Interviews with Experts}

For this study, we interviewed a group of experts in RE, childhood and museum education to understand which strategies and tools we could use to establish bridges between museums and schools and how we could develop dynamics that brought educational models closer together in person or digitally and include those schools that were geographically distant from the museums.

Our interviews were grounded on four key topics discussing how to establish partnerships between museums and schools and foster open, inclusive, innovative and creative approaches and develop educational programmes from early schooling which, through the arts and heritage, could enable channels to foster active and critical citizenship.

\subsubsection{Relations between Schools and Museums}

In the first round of questions we asked them about what they consider to be the elements to foster relationships between schools and museums, to understand how to generate dynamics that allow connecting the educational centres of museums with schools and vice versa. The interviewed experts agreed that first it is necessary to have a good level of political will at territorial level, as political support is needed to establish relations between museums and schools in the same locality, considering the uniqueness of educational plans in different regions, to develop synergic educational plans with a heritage territorial perspective that facilitates interaction between museums and schools.

The experts also mentioned that there is a need to have directors with the will to promote the educational role of museums as these must rethink educational spaces and invite schools, promoting an interaction that is consistent and aligned with the schools' curricula, providing spaces for the entire educational community.

Another issue mentioned by the experts was the importance of developing communication strategies from the museums side to contact teachers and schools, as the experts suggested that museums need to invite schools to visit the spaces and participate in their educational programmes, establishing channels to communicate with schools through newsletters, but furthermore, it is key that the education sections on their web pages are up to date with clear information about their pedagogic activities, events and stating the way to contact them, while showcasing their educative activities dedicated to schools.

They also argued that museums need to improve the ways in which they communicate with the schools, by ensuring they speak the same language, to it is clear for schools, teachers and educational communities what do they offer at an educational level and how schools can bring the museum experiences, practices, materials and activities to work in the classroom to ensure that the activities carried out in the museums can be transferred to the classrooms, to have a clear educational impact. 


\subsubsection{Relationships between Educators}

The second round of questions was focused on the relationships between educators, since a central element of the conversations was the role of the RE educator, whether in schools or museums. They considered that, to be able to exercise this role in a manner consistent with the principles of RE, educators must be good observers in order to understand the strategies that infants use in their learning process and document them while also taking care of the presentation and disposition of the materials and tools to be used for provoking children to explore, ask questions and generate hypotheses.

In addition, RE educators must be capable of preparing learning activities that allow experimentation, putting into play a series of strategies to consequently develop skills and cognitive processes both in schools and in museums. Educators must prepare projects that are focused on the needs and interests of children in their environmental context, maintaining the idea of full and comprehensive development and relating different languages in each project or proposal.

Therefore, educators in schools and museums need spaces that enable dialogue and co-creation to jointly decide which themes, methods and strategies to use for projects. This dialogue is essential to provide opportunities for the development of critical and creative thinking, as by exchanging points of view, educators can co-design projects that are inspired by their experiences, explorations or questions about the world.

For this reason, educators must document the interests of the children by recording their games, explorations and relationships both in the classroom and in museums to embed learning activities into the curriculum and promote development through the opportunities offered by exploring, experimenting, researching or teamwork. Thus, it is key that museums provide schools with guidance for the adoption of their activities, listing the objectives, competencies and core contents and the materials so teachers can work in the classroom before and after a museum visit.

\subsubsection{Space Design}

In the third round of questions, we discussed with the experts the issue of the design of the spaces, and from the analysis of the interviews, we can conclude that, firstly, the spaces must be functional, spacious and, if possible, open to the outside and accessible with modular materials and furniture that can be adapted to the needs of the students and to specific activities, facilitating experimentation and exploration through elements that provoke the inspiration and imagination of the students.

The experts mentioned the importance of allowing a controlled disorder in the spaces, understanding that kids can act and create freely in them, allowing the students to choose, observe, classify, compare, act, identify, analyse, evaluate and finally create through the use of a wide range of materials and emphasising the importance of using natural and recycled materials in experiential learning activities. However, the materials need to be selected while having in mind that educators need to intervene as little as possible in the learners' decision-making processes to create things.

It was noted that both the activities and materials must guarantee the safety of infants while providing the maximum possible autonomy. Thus, in the ateliers, the materials must be rotated and renewed to ensure that students can ask new questions while provoking new types of explorations, experimentations and manipulations, thereby enriching the learning process.

\subsubsection{Types of Activities That Can Be Developed}

Finally, we concluded the interviews by asking the experts what types of activities could be developed to stimulate the arts and heritage, both in face-to-face and online learning activities.

Thinking about the design of educational activities, among the most repeated actions by the experts during the interviews were observing the students, provoking situations, providing materials and resources, preparing activities, accompanying the children during 
the learning process, coordinating and organising activities and ideas, exploring results, supporting students and stimulating their learning.

Therefore, both schools and museums should observe the children and detect their interests and understand what kinds of activities, experimentations and explorations they preferred, then select the type of materials, giving special importance to the presence of materials of natural origins. Teachers and patrimonial educators must maintain good communication between them to be able to assess which types of activities generate more interest in children and, on the contrary, which ones do not generate the stimulus sought, then rethink, redesign and improve the pedagogic practices and educational experiences.

The experts highlighted the value of designing experiential learning activities grounded in the RE approach, as these can help museums and schools to conceive activities as a continuous process based on experience and enhance the extension of learning beyond the learning spaces. Thus, schools and museums should foster hands-on activities combined with the use of resources and artifacts in an inclusive, engaging, interactive and stimulating manner to enrich children's learning and experiences. However, for those students that cannot physically visit the museums, the experts mentioned that other activities, such as research or enquiry-based learning activities, could be carried out using the resources and materials provided by the museums.

It is quite interesting to note that in general lines, and in light of the results obtained, our interviewees questioned the standardised educational menus normally used for heritage and arts education, as they consider that, nowadays, it is key to work on increasingly personalised projects that ensure that children are the key protagonists in the construction of their learning so they can learn to critically assess phenomena, thus leading towards achieving a civic, critical and creative education.

\section{Discussion}

One of the pillars of the RE model is the co-creation of knowledge through negotiated learning for the development of skills such as critical thinking throughout activities that promote dialogue, debate and problem solving between students and the community, enhancing the research, exploration and experimentation skills that allow students to recognize, select, code and interpret information.

The RE approach encourages the establishment of relationships between the school and society, since it is understood that students need to communicate with others in order to learn. In this sense, the environment and specifically the atelier play an important role in the development of social skills, and it is considered an educational agent. This aspect becomes visible when analysing the practices of museums, seeing that their proposals are experiential and experimental, promoting creative proposals that allow children to explore, co-create and express ideas through projects and activities.

In the case of the RE approach, the openness of educational practices and museum resources is particularly important for developing programmes for the stimulation of critical thinking in early childhood by providing schools with innovative activities and materials in an open way while creating communities of pedagogical practices with early childhood education teachers to develop activities that can be carried out in museums and schools, thereby bringing museum collections to schools.

The debate on the importance of bringing students closer to museums has a long pedagogical tradition [130]. We dare to affirm that there is no teacher who doubts the need to take students to have an educational experience in a museum. In fact, one of the aspects that has become evident during the pandemic has been the fragile situation that museums experience at the public level and how the schools' visits nourish their daily life. Additionally, as we have said, it is practically unthinkable to think of school education that does not include museums as an educational agent.

There is, however, a concern observed and shared among the different educational agents that intervene in this approach, and that is that the educational actions often take place in parallel in the classroom and in the museum, missing a key moment of the peda- 
gogic collaborations, as both worlds only approach while the school visits the museums and then separate again, thus hindering what could be a great way to fix educational problems by promoting competence learning in the experiential model proposed by the museum, where the students have an active role in building their learning, which can be adopted in the classroom by consolidating a shared learning methodology grounded in RE principles to create bridges between museums and schools.

We also highlight the importance of opening up the collections and educational practices of museums through the establishment of strategic plans for open education, following the recommendations of UNESCO [111] through a model of co-creation of policies so that these are designed in an inclusive and participatory way [118] and in which educational value is added to the digitisation of museum collections and archives, since digitising must go beyond open access and the conservation of tangible and intangible heritage. Rather, it needs to benefit educational communities by facilitating access to collections and educational activities around them in an open, free, accessible and democratic manner.

The RE approach advocates for a pedagogic system where the environment is a vehicle for learning. Thus, it is essential for museum educators to generate a climate of respect and interaction among students that allows them to build their learning, fostering heritage education that gives a leading role to the students by transforming the role of the educator to someone that promotes participation by the students in their learning process. Thus, it is key to think about which kind of relationship we want to help establish between museums and schools and how to embed the RE principles and axis so they can easily be transferred in the educational actions of museums and schools, aiming to achieve richer results [131].

The RE model promotes that each person is responsible for their own learning. However, to learn we must listen to points of view that are different from ours, as perhaps the point of view of others enriches ours. Thus, learning activities in museums and schools must allow dialog to interrogate and question ourselves about what we are observing and listening to so we can learn from these interactions.

\section{Conclusions and Recommendations}

We consider that the RE philosophy provides an innovative and effective model that allows for rethinking the role of the arts and heritage education in early childhood education ( $0-5$ years) in order to experiment, investigate, formulate hypotheses, generate questions and, ultimately, develop critical thinking in young kids. As a result of the analysis of the literature, the practices of the museums and the interviews with the experts, we want to provide a series of recommendations for museums and educational centres aimed at serving as a guide to implement child education projects by adopting the philosophy, promoting the decentralisation of educational action towards learning activities shared between museums and schools.

The RE approach is useful for art education teachers and museum educators, since it allows in a simple and concrete way for establishing pedagogic parameters in the classroom atelier that generate opportunities for students to explore, experiment and ask themselves questions through projects based on the learners' interests, provoking critical thinking in students and making the learning process visible and not just the results.

To adopt the RE model in schools and museums and promote the development of skills in early childhood, we recommend this series of guidelines in relation to the environment, materials and activities that promote critical and creative thinking and the connection with society.

\subsection{Establishment of Museum-School Relations}

- Provide spaces to design experiential experiences that arise from students' interests about the world around them;

- Ensure that the activities connect the socioeducational reality of the students with the heritage history that is transmitted;

- Design activities that allow students to co-create, explore and express themselves; 
- Favor the presence of artistic, plastic and interpretative actions in activities;

- Provide spaces for schools and museums to co-create adequate, innovative and up-todate materials;

- Promote the co-designing of activities that can be worked both in school and in the museum instinctively;

- Open up spaces and round tables so educators can share educational methodologies;

- Ensure that the co-designed activities grant a leading role to the students;

- Ensure that the co-creation spaces for schools and museums design long-term projects to consolidate learning.

\subsection{Design of Environments and Teaching Materials in Schools and Museums}

We offer the following guidelines to design experiences that favour the autonomy and independence of students, through which they can feel free to investigate, experiment and create:

- Create spaces and settings that excite and surprise students;

- Present materials that offer students opportunities to experiment, observe and investigate through projects that allow them to question things;

- Create an environment that allows children to develop their creative capacity without limits or restrictions;

- Use tools that promote the use of the different languages that the child can use during the early stage through proposals that facilitate the child's expression;

- Develop digital guides in open formats to provide teachers with information on how to carry out activities, detailing the steps and materials to use;

- Open access to the museum's contents in downloadable and printable formats so that teachers can use them in classroom activities;

\subsection{Design of Activities That Promote the Development of Critical and Creative Thinking}

- Adopt dialogic methodologies that allow situations for debate, discussion and assembly;

- Adopt the arts as a vehicle to enhance the cognitive development of the student through creative proposals;

- Promote projects based on problem solving that allow students to think critically;

- Provide experimentations and activities that allow the student to acquire autonomy and independence;

- Encourage teamwork to enable the exchange of points of view and dialogue among equals.

\subsection{Establishment of Museum-Society Links}

- Create exhibitions that allow sharing the child's learning process with society;

- Collaborate and report periodically with families, making them participants in the students' learning;

- Hold open workshops in museums so that children can experience the essence of the atelier.

\subsection{Opening Pedagogies in Museums}

- Implement cohesive open access and open education policies to freely access digitised content and educational guides that are generated around them;

- Develop strategic teaching plans oriented for different stages so that teachers of different subjects can use and adapt them;

- Implement pedagogical tables so that schoolteachers and museum educators can co-create pedagogic content;

- Invite teachers from outside the place where the museum is located to have virtual encounters and remote activities to bring together remote educational communities through the use of ICTs;

- Provide educational materials in different formats that are inclusive so that they are useful for different groups of students; 
- Include digitised collections and teaching guides in education and open access portals such as Wikimedia Commons;

- Include clear information on the web pages about what educational proposals are offered by museums, including access to pedagogic materials and the type of open license associated with them.

7.6. Design of Pedagogic Activities at the University Level for Students in Museum, Heritage and Early Childhood Study Programmes

- Develop practical guidance for students to understand the role of the RE approach in creating bridges between schools and museums;

- Design experiential learning opportunities for students so they can visit schools and museums to understand how learning activities are designed;

- Invite students to explore and discover different school-museum educational programmes and examine their strengths and weaknesses;

- $\quad$ Organise cross-disciplinary round tables where the students can exchange ideas and experiences, documenting relevant practices;

- Invite museum and school educators to discuss with the students the curriculum design and the challenges faced by schools and museums;

- Design educational activities to teach students how to open up teaching and learning materials, supporting them in understanding the complexities of copyright and open licensing;

- Help students learn how to develop teaching plans and support different groups of learners in an inclusive way;

- Provide learning opportunities for students to learn how to co-create and co-design pedagogic activities bridging museums and schools;

- Provide students with practical experience in developing policies and strategies to bridge school and museum pedagogic activities by reviewing existing ones to identify good practices for establishing relationships between schools and museums.

Author Contributions: Conceptualization, M.F.-T. and M.F.-S.; methodology, M.F.-T. and J.A.; software, J.A.; validation, M.F.-T., M.F.-S. and J.A.; formal analysis, M.F.-T., M.F.-S. and J.A.; investigation, M.F.-T. and J.A.; data curation, M.F.-S.; writing—original draft preparation, M.F.-T., M.F.-S. and J.A.; writing-review and editing, J.A. All authors have read and agreed to the published version of the manuscript.

Funding: This research received no external funding.

Institutional Review Board Statement: Not applicable.

Informed Consent Statement: Not applicable.

Data Availability Statement: Not applicable.

Conflicts of Interest: The authors declare no conflict of interest.

\section{References}

1. Malaguzzi, L. La Educación Infantil en Reggio Emilia; Ediciones Octaedro: Barcelona, Spain, 1993.

2. Rankin, B. Education as collaboration: Learning from and building on Dewey, Vygotsky, and Piaget. In First Steps toward Teaching the Reggio Way; Hendrick, J., Ed.; Prentice-Hall: Upper Saddle River, NJ, USA, 1997; pp. 70-83.

3. Sassalos, M. With Dr. Abigail. S. McNamee Fall Discovering Reggio Emilia, Building Connections between Art and Learning. 1999. Available online: http:/ / eric.ed.gov/?id=ED456890 (accessed on 24 March 2021).

4. Bersaluce Díez, R. La Calidad Como Reto en las Escuelas de Educación Infantil al Inicio del s. XXI: Las Escuelas de Reggio Emilia, de Loris Malaguzzi, Como Modelo a Seguir en la Práctica Educativa. Ph.D. Thesis, Universidad de Alicante, Alicante, Spain, 2008. Available online: https:/ / rua.ua.es/dspace/bitstream/10045/11273/1/tesis_Rosario_Berasaluce.pdf (accessed on 24 March 2021).

5. Gonzalez-Sanz, M.; Feliu-Torruella, M. Educación Patrimonial e Identidad. El Papel de los Museos en la Generación de Cohesión Social y de Vínculos de Pertenencia a una Comunidad. Clío: History and History Teaching. 2015. Available online: http:/ / clio.rediris.es/n41/articulos/gonzalezFeliu2015.pdf (accessed on 24 March 2021). 
6. Filipini, T. The role of the pedagogista. In The Hundred Languages of Children: The Reggio Emilia Approach-Advanced Reflections, 2nd ed.; Edwards, C., Gandini, L., Forman, Y.G., Eds.; Ablex Publishing Corporation: Greenwich, CT, USA, 1998 ; pp. $127-137$.

7. Oken-Wright, P. Documentation: Both Mirror and Light. Innovations in Early Education: The International Reggio Exchange. 2001. Available online: https:/ / www.reggioalliance.org/downloads/documentation:okenwright.pdf (accessed on 24 March 2021).

8. Kirk, E. A School Trip for Reggio Emilia: Enhancing Child-Led Creativity in Museums. In Creative Engagements with Children: International Perspectives and Contexts; Brill: Leiden, The Netherlands, 2012; pp. 133-141.

9. Feliu-Torruella, M.; Torregrosa, L.J. Descubro, Descubren, Descubrimos Juntos. Aula de Infantil. 2015. Available online: https: / / dialnet.unirioja.es/servlet/articulo?codigo=5195424 (accessed on 24 March 2021).

10. Merillas, O.F.; Etxeberria, A.I. Estrategias e instrumentos para la educación patrimonial en España. Educ. Siglo XXI 2015, 33, 15-32. [CrossRef]

11. Merillas, O.F.; Ceballos, S.G.; Arias, B.; Arias, V.B. Assessing the Quality of Heritage Education Programs: Construction and Calibration of the Q-Edutage Scale. Rev. Psicodidáctica 2019, 24, 31-38. [CrossRef]

12. Firlik, R. Can we adapt the philosophies and practices of Reggio Emilia, Italy, for use in American schools? J. Fam. Econ. Issues 1996, 23, 217-220. [CrossRef]

13. Edwards, C. Partner, nurturer, and guide: The roles of the Reggio teacher in action. In The Hundred Languages of Children: The Reggio Emilia Approach to Early Childhood Education; Edwards, C., Gandini, L., Forman, G., Eds.; Ablex: Norwood, NJ, USA, 1993; pp. 151-169.

14. Feliu-Torruella, M. Metodologías de enseñanza y aprendizaje del arte en la Educación Primaria. Didáctica de las Cien-Cias Experimentales y Sociales 2011, 25, 85-102.

15. Cuenca López, J.M.; Martín-Marín, M.J. Manual para el desarrollo de proyectos educativos de museos. Educatio Siglo XXI 2015, 33, 347-350.

16. Piscitelli, B.; Anderson, D. Young children's Perspectives of Museum Settings and Experiences. Mus. Manag. Curatorship 2001, 19, 269-282. [CrossRef]

17. Anderson, D.; Piscitelli, B.; Weier, K.; Everett, M.; Tayler, C. Children's Museum Experiences: Identifying Powerful Mediators of Learning. Curator Mus. J. 2002, 45, 213-231. [CrossRef]

18. Weier, K. Empowering Young Children in Art Museums: Letting them take the lead. Contemp. Issues Early Child. 2004, 5, 106-116. [CrossRef]

19. Moran, M.J.; DesRochers, L.; Cavicchi, N.M. Progettazione and Documentation as Sociocultural Activities: Changing Communities of Practice. Theory Pract. 2007, 46, 81-90. [CrossRef]

20. Beresaluce Díez, R. Las escuelas reggianas como modelo de calidad en la etapa de educación infantil. Aula Abierta 2009, 37, 123-130.

21. Feliu-Torruella, M. Cómo Podemos Aprender el Arte en Educación Primaria? Traslademos las Obras de Arte al Aula!. Educación Artística: Revista de Investigación (EARI). 2011. Available online: https://dialnet.unirioja.es/descarga/articulo/4358396.pdf (accessed on 24 March 2021).

22. Blanco, M. Qué es la Filosofía Educativa Reggio Emilia? 2017. Available online: https://www.lacasitadeingles.com/single-post/ ReggioEmilia (accessed on 24 March 2021).

23. Edwards, C. Fine Designs" from Italy: Montessori Education and the Reggio Approach. Faculty Publications, De-partment of Child, Youth, and Family Studies. 2003. Available online: https:/ / digitalcommons.unl.edu/cgi/viewcontent.cgi?article=1019 \&context=famconfacpub (accessed on 24 March 2021).

24. Cutcher, A.L. Art Spoken Here: Reggio Emilia for the Big Kids. Int. J. Art Des. Educ. 2013, 32, 318-330. [CrossRef]

25. Salas, A.L.C. Implicaciones educativas de la teoría sociocultural de Vigotsky. Rev. Educ. 2011, 25, 59. [CrossRef]

26. Carrera, B.; Mazzarella, C. Vygotsky: Enfoque Sociocultural. Educere. Available online: https://eric.ed.gov/?id=EJ474756 (accessed on 24 March 2021).

27. Jové Monclús, G.; Betrián Villas, E.; Ayuso, H.; Vicens, L. Proyecto Educ-Arte-Educa (r) t: Espacio Híbrido. Rev. Educ. 2012, 35, 177-196. Available online: https:/ / repositori.udl.cat/handle/10459.1/56974EJ474756 (accessed on 24 March 2021).

28. Gomez Carrasco, C.; Pérez, R.A.R. Aprender a enseñar ciencias sociales con métodos de indagación. Los estudios de caso en la formación del profesorado. Rev. Docencia Univ. 2014, 12, 307-325. [CrossRef]

29. Veraksa, N.; Shiyan, O.; Shiyan, I.; Pramling, N.; Pramling-Samuelsson, I. Communication between teacher and child in early child education: Vygotskian theory and educational practice/La comunicación entre profesor y alumno en la educación infantil: La teoría vygotskiana y la práctica educativa. Infanc. Aprendiz. 2016, 39, 221-243. [CrossRef]

30. Giménez, J.E.; Ávila Ruiz, R.M.; Listán, M.F. Primary and secondary teachers' conceptions about heritage and heritage education: A comparative analysis. Teach. Teach. Educ. 2008, 24, 2095-2107. [CrossRef]

31. Pacini-Ketchabaw, V.; Kind, S.; Kocher, L.L.M. Encounters with Materials in Early Childhood Education; Routledge India: New Delhi, India, 2016.

32. Potočnik, R. Effective approaches to heritage education: Raising awareness through fine art practice. Int. J. Educ. Through Art 2017, 13, 285-294. [CrossRef]

33. Rivero, P.; Merillas, O.F.; García-Ceballos, S.; Rodríguez, M.M. Heritage Education in The Archaeological Sites. An Identity Approach in The Museum of Calatayud. Curator Mus. J. 2018, 61, 315-326. [CrossRef] 
34. Poce, A.; Agrusti, F.; Re, M.R. Heritage Education and Initial Teacher Training: An International Experience. 2018. Available online: https: / / www.learntechlib.org/p/184460/ (accessed on 24 March 2021).

35. Rodríguez, M.M.; Merillas, O.F. Dealing with heritage as curricular content in Spain's Primary Education. Curric. J. 2020, 31, 77-96. [CrossRef]

36. Trabajo-Rite, M.; Cuenca-López, J.M. Student Concepts after a Didactic Experiment in Heritage Education. Sustain. J. Rec. 2020, 12, 3046. [CrossRef]

37. Abramson, S.; Robinson, R.; Ankenman, K. Project Work with Diverse Students: Adapting Curriculum Based on the Reggio Emilia Approach. Child. Educ. 1995, 71, 197-202. [CrossRef]

38. Bresler, L. "Child Art," "Fine Art," and "Art for Children": The Shaping of School Practice and Implications for Change. Arts Educ. Policy Rev. 1998, 100, 3-10. [CrossRef]

39. Flutter, J. Teacher development and pupil voice. Curric. J. 2007, 18, 343-354. [CrossRef]

40. Gupta, P.; Adams, J.; Kisiel, J.; Dewitt, J. Examining the complexities of school-museum partnerships. Cult. Stud. Sci. Educ. 2010, 5, 685-699. [CrossRef]

41. Drew, V.; Mackie, L. Extending the constructs of active learning: Implications for teachers' pedagogy and practice. Curric. J. 2011, 22, 451-467. [CrossRef]

42. Torrance, E.P. Rationale of the Torrance Tests of Creative Thinking Ability. Torrance; White, F., Peacock, E., Eds.; The Council for Exceptional Children: Illinois, IL, USA, 1969.

43. Runco, M.A.; Jaeger, G.J. The Standard Definition of Creativity. Creat. Res. J. 2012, 24, 92-96. [CrossRef]

44. Runco, M.; Acar, S.; Campbell, W.K.; Jaeger, G.; McCain, J.; Gentile, B. Comparisons of the Creative Class and Regional Creativity with Perceptions of Community Support and Community Barriers. Bus. Creat. Creat. Econ. 2016, 2, 83-92. [CrossRef]

45. Gandini, L. Fundamentals of the Reggio Emilia approach to early childhood education. Young Child. 1993, 49, 4-8.

46. Bredekamp, S. Reflections on Reggio Emilia. Young Child. 1993, 49, 13-17.

47. Tarr, P. Aesthetic Codes in Early Childhood Classrooms: What Art Educators Can Learn from Reggio Emilia. Art Educ. 2001, 54, 33. [CrossRef]

48. New, R.S. Reggio Emilia As Cultural Activity Theory in Practice. Theory Prac. 2007, 46, 5-13. [CrossRef]

49. Vecchi, V. Art and Creativity in Reggio Emilia: Exploring the Role and Potential of Ateliers in Early Childhood Education; Routledge: New York, NY, USA, 2010.

50. Falk, J.H.; Dierking, L.D. Learning from Museums: Visitor Experiences and the Making of Meaning; Altamira Press: Lanham, MD, USA, 2000.

51. Allard, M.; Boucher, S.; Forest, L. The Museum and the School. 1994. Available online: http://mje.mcgill.ca/article/view/8169 (accessed on 24 March 2021).

52. Feliu-Torruella, M.; Triadó, A. Interactuando con Objetos y Maquetas. Iber: Didáctica de las Ciencias Sociales, Geografía e Historia. 2011. Available online: https:/ / dialnet.unirioja.es/servlet/articulo? codigo=3616666 (accessed on 24 March 2021).

53. Strong-Wilson, T.; Ellis, J. Children and Place: Reggio Emilia's Environment as Third Teacher. Theory Into Prac. 2007, 46, 40-47. [CrossRef]

54. Schroeder-Yu, G. Documentation: Ideas and Applications from the Reggio Emilia Approach. Teach. Artist J. 2008, 6, 126-134. [CrossRef]

55. Reynolds, G. Reggio Emilia-An Impossible Dream? Can. Child. 1998, 23, 4-10.

56. Bennet, T. Reactions to Visiting the Infant-Toddler and Preschool Centers in Reggio Emilia, Italy. Early Research and Practice. 2001. Available online: https:/ / files.eric.ed.gov/fulltext/ED453001.pdf (accessed on 24 March 2021).

57. Fraser, S. Authentic Childhood: Experiencing Reggio Emilia in the Classroom, 2nd ed.; Thomson Nelson: Toronto, ON, Canada, 2006.

58. Eckhoff, A.; Spearman, M. Rethink, Reimagine, Reinvent: The Reggio Emilia Approach to Incorporating Reclaimed Materials in Children's Artworks. Art Educ. 2009, 62, 10-16. [CrossRef]

59. Katz, L. What Can We Learn from Reggio Emilia? The Hundred Languages of Children: The Reggio Emilia ApproachAdvanced Reflections. 1993. Available online: https:/ /www.theartofed.com/content/uploads/2015/05/What-We-Can-LearnFrom-Reggio.pdf (accessed on 24 March 2021).

60. Loh, A. Reggio Emilia Approach. 2006. Available online: http://www.brainy-child.com/article/reggioemilia.shtml (accessed on 24 March 2021).

61. Swann, A.C. Children, Objects, and Relations: Constructivist Foundations in the Reggio Emilia Approach. Stud. Art Educ. 2008, 50, 36-50. [CrossRef]

62. Casey, E.M.; Dicarlo, C.F.; Sheldon, K.L. Growing democratic citizenship competencies: Fostering social studies understandings through inquiry learning in the preschool garden. J. Soc. Stud. Res. 2019, 43, 361-373. [CrossRef]

63. Edwards, C. Three Approaches from Europe: Waldorf, Montessori, and Reggio Emilia. Early Childhood Research \& Practice. 2002. Available online: https:/ / files.eric.ed.gov/fulltext/ED464766.pdf (accessed on 24 March 2021).

64. McClure, M. Spectral Childhoods and Educational Consequences of Images of Children. Visual Arts Research. 2009. Available online: http:/ / www.jstor.org/stable/20715506?seq=1\#page_scan_tab_contents (accessed on 24 March 2021).

65. Torraco, R.J. Writing Integrative Literature Reviews: Guidelines and Examples. Hum. Resour. Dev. Rev. 2005, 4, 356-367. [CrossRef] 
66. De Souza, M.T.; Da Silva, M.D.; De Carvalho, R. Integrative review: What is it? How to do it? Einstein 2010, 8, 102-106. [CrossRef] [PubMed]

67. Grant, M.J.; Booth, A. A typology of reviews: An analysis of 14 review types and associated methodologies. Heal. Inf. Libr. J. 2009, 26, 91-108. [CrossRef]

68. Jesson, J.; Matheson, L.; Lacey, F.M. Doing Your Literature Review: Traditional and Systematic Techniques; Sage Publications: London, $\mathrm{UK}, 2011$.

69. Rocco, T.S.; Plakhotnik, M.S. Literature Reviews, Conceptual Frameworks, and Theoretical Frameworks: Terms, Functions, and Distinctions. Hum. Resour. Dev. Rev. 2009, 8, 120-130. [CrossRef]

70. Torraco, R.J. Writing Integrative Reviews of the Literature. Int. J. Adult Vocat. Educ. Technol. 2016, 7, 62-70. [CrossRef]

71. Martín-Martín, A.; Orduna-Malea, E.; López-Cózar, E.D. Coverage of highly-cited documents in Google Scholar, Web of Science, and Scopus: A multidisciplinary comparison. Science 2018, 116, 2175-2188. [CrossRef]

72. Moher, D.; Liberati, A.; Tetzlaff, J.; Altman, D.G.; The PRISMA Group. Preferred reporting items for systematic reviews and meta-analyses: The PRISMA statement. PLoS Med. 2009, 6, e1000097. [CrossRef]

73. Santín, M.F.; Torruella, M.F. Reggio Emilia: An Essential Tool to Develop Critical Thinking in Early Childhood. J. New Approaches Educ. Res. 2017, 6, 50-56. [CrossRef]

74. Fernández-Santín, M.; Feliu-Torruella, M. Developing critical thinking in early childhood through the philosophy of Reggio Emilia. Think. Ski. Creat. 2020, 37, 100686. [CrossRef]

75. Downey, S.; DeLamatre, J.; Jones, J. Measuring the Impact of Museum-School Programs: Findings and Implications for Practice. J. Mus. Educ. 2007, 32, 175-187. [CrossRef]

76. Bobick, B.; Hornby, J. Practical Partnerships: Strengthening the Museum-School Relationship. J. Mus. Educ. 2013, 38, 81-89. [CrossRef]

77. Cuenca, L.G.; Gorospe, J.M.C.; de Aberasturi Apraiz, E.J.; Etxeberria, A.I. El modelo reflexivo en la formación de maestros y el pensamiento narrativo: Estudio de un caso de innovación educativa en el Practicum de Magisterio The reflexive model in teacher training and narrative thinking: A case study of educational innovation in the. Rev. Educ. 2009, 350, 493-505.

78. Witmer, S.; Luke, J.; Adams, M. Exploring the potential of museum multiple-visit programs. Art Educ. 2000, 53, 46-54. [CrossRef]

79. Barragree, C. Museum and Public School Partnerships: A Step-by-Step Guide for Creating Standards-Based Curriculum Materials in High School Social Studies. 2007. Available online: http://krex.k-state.edu/dspace/handle/2097/286 (accessed on 24 March 2021).

80. Kundu, R. A Collaborative Affair: The Building of Museum and School Partnerships. 2010. Available online: http:// citeseerx.ist. psu.edu/viewdoc/download?doi=10.1.1.840.3376\&rep=rep1\&type=pdf (accessed on 24 March 2021).

81. Witmer, S. A Neighborhood Partnership: Art Around the Corner. Docent Educ. 2000, 10, 1. Available online: http://www. museum-ed.org/a-neighborhood-partnership-art-around-the-corner/ (accessed on 24 March 2021).

82. Elliot, J.R. The Infinity and Beyond: Museum-School Partnerships beyond the Field Trip. 2012. Available online: http:// scholarship.shu.edu/cgi/viewcontent.cgi?article=1217\&context=theses (accessed on 24 March 2021).

83. Cuenca López, J.M.; Martín Cáceres, M.J.; Ibáñez Etxeberria, A.; Fontal Merillas, O. La Educación Patrimonial en Las Instituciones Patrimoniales Españolas: Situación Actual y Perspectivas de Futuro. 2014. Available online: http://rabida.uhu.es/dspace/ handle/10272/12927 (accessed on 24 March 2021).

84. Fiore, A. The Reggio Emilia Approach to Early Childhood. Newsweek. 1991. Available online: https://tykesntotsdaycare.weebly. com/uploads/5/3/9/7/53974635/the_reggio_emilia_approach_to_early_childhood.pdf (accessed on 24 March 2021).

85. Hoyuelos, A. Reggio Emilia y la Pedagogía de Loris Malaguzzi. Revista Novedades Educativas. 2004. Available online: http:/ / www.redsolare.com/new2/hoyuelos.pdf (accessed on 24 March 2021).

86. Forman, G.; Kuschner, D. The Child's Construction of Knowledge: Piaget for Teaching Children; The National Association for the Education of Young Children: Washington, WA, USA, 1983.

87. Forman, G. Different Media, Different Languages. Reflections on the Reggio Emilia approach. 1994. Available online: https: / / files.eric.ed.gov / fulltext/ED375932.pdf (accessed on 24 March 2021).

88. Burchenal, M.; Grohe, M. Thinking through Art: Transforming Museum Curriculum. J. Mus. Educ. 2007, 32, 111-122. [CrossRef]

89. Ingham, B. El Arte y el Patrimonio: Una nueva perspectiva en la educación. In Patrimonio e Identidad; Monasterio de Santa María La Real de Las Huelgas: Burgos, Spain, 2011; pp. 28-29.

90. Coll, C. Enseñar y aprender, construir y compartir: Procesos de aprendizaje y ayuda educativa. In Desarrollo, Aprendizaje y Enseñanza en la Educación Secundaria; Graó: Barcelona, Spain, 2010; pp. 31-62.

91. Edwards, C.; Gandini, L.; Forman, G. (Eds.) The Hundred Languages of Children: The Reggio Emilia Approach to Early Childhood Education; Ables: Norwood, NJ, USA, 1993.

92. Kim, B.S.; Darling, L.F. Monet, Malaguzzi, and the Constructive Conversations of Preschoolers in a Reggio-Inspired Classroom. J. Fam. Econ. Issues 2009, 37, 137-145. [CrossRef]

93. Vakil, S.; Freeman, R.; Swim, T.J. The Reggio Emilia Approach and Inclusive Early Childhood Programs. J. Fam. Econ. Issues 2003, 30, 187-192. [CrossRef]

94. Perret-Clermont, A.N. Social Interaction and Cognitive Development in Children; Academic Press: London, UK, 1980. 
95. Forman, G.; Fyfe, B. Negotiated learning through design, documentation and discourse. In The Hundred Languages of Children: The Reggio Emilia Approach-Advanced Reflections, 2nd ed.; Edwards, C., Gandini, L., Forman, Y.G., Eds.; Ablex Publishing Corporation: Greenwich, UK, 1998; pp. 239-260.

96. Flavell, J.H. Cognitive Development: Children's Knowledge about the Mind. Annu. Rev. Psychol. 1999, 50, 21-45. [CrossRef] [PubMed]

97. Gimeno Sacristán, J.; Gómez, P. Comprender y Transformar la Enseñanza; Editorial Morata: Madrid, Spain, 2002.

98. Quesada, A.; García, A.; Jiménez, J. Geografía e historia. In Profesores de Enseñanza Secundaria; Volumen Práctico; Editorial Mad: Madrid, Spain, 2003.

99. Pindado, J. Las Posibilidades Educativas de los Videojuegos. Una Revisión de los Estudios más Significativos. 2005. Available online: https://idus.us.es/bitstream/handle/11441/45601/file_1.pdf (accessed on 24 March 2021).

100. Bagayogo, F.; Lapointe, L.; Ramaprasad, J.; Vedel, I. Co-creation of Knowledge in Healthcare: A Study of Social Media Usage In Proceedings of the 2014 47th Hawaii International Conference on System Sciences, Institute of Electrical and Electronics Engineers (IEEE), Waikoloa, HI, USA, 6-9 January 2014; pp. 626-635.

101. Adams, B.L. Nursing education for critical thinking: An integrative review. J. Nurs. Educ. 1999, 38, 111-119. [CrossRef] [PubMed]

102. Ovi, A. Cheese, Children, and Container Cranes: Learning from Reggio Emilia. Daedalus 2001, 130, 105-118.

103. Wexler, A. A Theory for Living: Walking with Reggio Emilia. Art Educ. 2004, 57, 13. [CrossRef]

104. Samuelsson, I.P.; Sheridan, S.; Williams, P. Five preschool curricula-Comparative perspective. Int. J. Early Child. 2006, 38, 11-30. [CrossRef]

105. Gilman, S. Including the Child with Special Needs: Learning from Reggio Emilia. Theory Pract. 2007, 46, 23-31. [CrossRef]

106. Bean, J.C. Engaging Ideas: The Professor's Guide to Integrating Writing, Critical Thinking, and Active Learning in the Classroom; John Wiley \& Sons: Toronto, ON, Canada, 2011.

107. Thompson, C. Critical Thinking across the Curriculum: Process over Output. Int. J. Humanit. Social Sci. $2011,1,1-7$.

108. Gokhale, A.A. Collaborative Learning and Critical Thinking. In Encyclopedia of the Sciences of Learning; Metzler, J.B., Ed.; Springer: Boston, MA, USA, 2012; pp. 634-636.

109. Fontal-Merillas, O. El patrimonio a través de la educación artística en la etapa de primaria. Arte Individ. Soc. 2016, 28, 105-120. [CrossRef]

110. UNESCO. 2012 Paris OER Declaration. World OER Congress, Paris. June 2012. Available online: https://en.unesco.org/oer/ paris-declaration (accessed on 24 March 2021).

111. UNESCO. UNESCO Recommendation on OER. Paris: UNESCO Publications. 2020. Available online: https://en.unesco.org/ themes/building-knowledge-societies/oer/recommendation (accessed on 24 March 2021).

112. Cronin, C. Openness and Praxis: Exploring the Use of Open Educational Practices in Higher Education. Int. Rev. Res. Open Distrib. Learn. 2017, 18, 15-34. [CrossRef]

113. Rodeés, V. Una Teoriía Fundamentada sobre la Adopción de Repositorios y Recursos Educativos Abiertos en universidades lati-noamericanas. In Centro Internacional de Estudos de Doutoramento e Avanzados (CIEDUS), Programa de Doutoramento en Equidade e Innovación en Educación; Universidade de Santiago de Compostela: Santiago de Compostela, Spain, 2019.

114. Havemann, L. Open in the Evening. In Open(ing) Education; Brill: Leiden, The Netherlands, 2020; pp. 329-344.

115. Harley, D. Why understanding the use and users of open education matters. In Opening Up Education: The Collective Advancement of Education through Open Technology, Open Content, and Open Knowledge; The MIT Press: London, UK, 2008; pp. 197-211.

116. Van Mourik Broekman, P.; Hall, G.; Byfield, T.; Hides, S.; Worthington, S. Open Education: A Study in Disruption; Rowman \& Littlefield: London, UK, 2014.

117. Bayne, S.; Jandrić, P. From anthropocentric humanism to critical posthumanism in digital education. Knowl. Cult. 2017, 5, 197. [CrossRef]

118. Atenas, J.; Havemann, L.; Neumann, J.; Stefanelli, C. Open Education Policies: Guidelines for co-creation. Open Educ. Policy Lab. 2020. [CrossRef]

119. Peters, M.A. The History and Emergent Paradigm of Open Education. In Open Education and Education for Openness; Sense Publishers: Rotterdam, The Netherlands, 2008; pp. 1-15.

120. Peters, M.A.; Britez, R.G. (Eds.) Open Education and Education for Openness; Sense Publishers: Rotterdam, The Netherlands, 2008.

121. Edwards, R. Knowledge infrastructures and the inscrutability of openness in education. Learn. Media Technol. 2012, 40, 251-264. [CrossRef]

122. Bautista, S.S.; Balsamo, A. Understanding the distributed museum: Mapping the spaces of museology in contem-porary culture. In Museums and Higher Education Working Together; Routledge: New York, NY, USA, 2016; pp. 55-70.

123. Bayne, S.; Knox, J.; Ross, J. Open education: The need for a critical approach. Learn. Media Technol. 2015, 40, 247-250. [CrossRef]

124. Hein, G.E. Progressive Museum Practice: John Dewey and Democracy; Routledge: New York, NY, USA, 2016.

125. Truyen, F.; Colangelo, C.; Taes, S. What can Europeana Bring to Open Education? Enhancing European Higher Education "Opportunities and Impact of New Modes of Teaching". 2016. Available online: https://lirias.kuleuven.be/1811113?limo=0 (accessed on 24 March 2021).

126. Daniela, L. Virtual Museums as Learning Agents. Sustain. J. Rec. 2020, 12, 2698. [CrossRef]

127. Williams, B.L. Recent Changes in Museum Education with Regard to Museum-School Partnerships and Discipline-Based Art Education. 1997. Available online: https:/ / www.jstor.org/stable/20715917 (accessed on 24 March 2021). 
128. Jové Monclús, G.; Moroba, S.C.; Moli, H.A.; Plana, R.S. Experiencia de Arte y Educación. La Escuela va al Centro de Arte y el Centro de Arte va a la Escuela. In Los Museos en la Educación: La Formación de los Educadores: I Congreso Internacional: Actas, Ponencias y Comunicaciones. Fundación Colección Thyssen-Bornemisza. 2009. Available online: https://dialnet.unirioja.es / servlet/articulo?codigo=6375396 (accessed on 24 March 2021).

129. Super, C.M.; Harkness, S. The Developmental Niche: A Conceptualization at the Interface of Child and Culture. Int. J. Behav. Dev. 1986, 9, 545-569. [CrossRef]

130. Alderoqui, S.; Pedersoli, C. La Educación en los Museos: De los Objetos a los Visitantes; Ediciones Paidós: Buenos Aires, Argentina, 2011.

131. González-Sanz, M.; Feliu-Torruella, M.; Cardona-Gómez, G. Las Visual Thinking Strategies (VTS) desde la perspectiva del educador patrimonial. DAFO del método en su aplicación práctica: Visual Thinking Strategies from the perspectives of museum educators': A SWOT analysis of the method's practical implementation. Rev. Educ. 2017, 375, 160-182. [CrossRef] 